\title{
Scutellinia (Pezizales) In Korea, With A New Species and Eight New Records
}

\section{Citation}

Choi, Young-Joon Choi, Hyeon-Dong Shin, Jae-Gu Han, and Donald H. Pfister. Forthcoming. Scutellinia (Pezizales) in Korea, with a new species and eight new records. Nova Hedwigia 95(3-4).

\section{Permanent link}

http://nrs.harvard.edu/urn-3:HUL.InstRepos:9570031

\section{Terms of Use}

This article was downloaded from Harvard University's DASH repository, and is made available under the terms and conditions applicable to Open Access Policy Articles, as set forth at http:// nrs.harvard.edu/urn-3:HUL.InstRepos:dash.current.terms-of-use\#OAP

\section{Share Your Story}

The Harvard community has made this article openly available.

Please share how this access benefits you. Submit a story.

Accessibility 
1 Scutellinia (Pezizales) in Korea, with a new species and eight new records

2

3 By

4 Young-Joon Choi ${ }^{1}$, Hyeon-Dong $\mathrm{Shin}^{2}$, Jae-Gu Han ${ }^{2}$, Donald H. Pfister ${ }^{1 *}$

5

$6{ }^{1}$ Department of Organismic and Evolutionary Biology, Harvard University, Cambridge, MA 7 02138, USA

$8 \quad{ }^{2}$ Division of Environmental Science and Ecological Engineering, Korea University, Seoul 1369701 , Korea

10

11

12
*Corresponding author: D.H. Pfister

E-mail: dpfister@oeb.harvard.edu

Phone:

$+1-617-495-2368$

With 2 figures

Choi, Y.J., H.D. Shin, J.G. Han \& D.H. Pfister (2012): Scutellinia (Pezizales) in Korea, with a new species and eight new records. - Nova Hedwigia xx: xx-xx.

Abstract: Eleven species of the genus Scutellinia (Pyronemataceae, Pezizales) are recognized in Korea by analysis of macro- and micro-morphological characteristics, substrates and geographical distributions. Eight species are recorded new to Korea, namely, S. ahmadiopsis, $S$. badio-berbis, S. colensoi, S. jilinensis, S. nigrohirtula, S. olivascens, S. setosa and S. patagonica. Based on the exceptional length of marginal hairs and tuberculate ascospore wall ornamentation, two Korean specimens occurring on wood are described as a new species. Infraspecific morphological variations among collections within S. scutellata and S. patagonica were found. These are tentative treat as species complexes. The highly questionable occurrence of $S$. setosa in Asia was confirmed. Descriptions and taxonomic notes of the recognized species of Scutellinia are provided with a taxonomic key, illustrations and photographs of these species from Korea. 
Keywords: Ascomycete, East Asia, Scutellinia erinaceus, S. kerguelensis, S. umbrarum, wall ornamentation

40

\section{Introduction}

The genus Scutellinia (Cooke) Lambotte is one of the genera with the most species in the Pyronemataceae (Pezizales, Ascomycota). Cooke (1879) first employed the name Scutellinia as a subgenus of Peziza; it was elevated to generic rank by Lambotte (1887). The name Scutellinia has a confusing history; many earlier authors used the names Patella F.H.Wigg., Ciliaria Quél. ex Boud. or Lachnea (Fr.) Gillet for these species. Applying a narrow generic concept Le Gal (1953) adopted the name Scutellinia instead of the invalid Ciliaria that had been favored by many workers. Her restricted concept has been widely adopted in the taxonomic literature (Korf \& Schumacher 1986, Schumacher 1990 and citations referred therein). This cosmopolitan genus is easily recognized by its shield-like red or orange apothecia, globose to ellipsoidal ascospores with or without various wall ornamentations, and stiff, long, blackish-brown hairs that arise from inner cells of the ectal excipulum. In considering the delimitation of species morphological characters were used as well habitat information and geographic distribution. Among the characters that have previously been used in defining species, hair morphology and ascospore shape and ornamentation have been especially emphasized in most keys at the infrageneric and species level (Bogacheva \& Kullman 2006, Donadini 1983, Gamundí 1956, 1975, Hansen \& Knudsen 2000, Kullman 1982, Le Gal 1972, 1974, Mato ec 2000, Moravec 1974, Schumacher 1979, 1990, Svrček 1971). Two different types of hairs were distinguished in Scutellinia species. Schumacher (1990) termed them "marginal hairs," those at or near the margin of apothecia, and "lateral hairs," those on the receptacle lower down. In some Scutellinia species, the marginal hairs are longer and broader than lateral hairs and have extensively forked or divided bases. Kullman (1982) and Schumacher (1990) referred to the hairs as "differentiated" when marginal and lateral hairs could easily be distinguished from one another and as "not differentiated" when they were too similar to discriminate. We follow their terminology in our descriptions.

Despite considerable taxonomic study of the genus, species delimitation and infrageneric subdivision within Scutellinia have remained problematic. Molecular phylogenetic approaches have been applied at the species level to other members of the Pyronemataceae, e.g. Otidea (Pers.) Bonord. (Liu \& Zhuang 2006), Chaetothiersia Perry \& Pfister (Perry \& Pfister 2008) and Geopora Harkn. (Tamm et al. 2010), but only a scattering of species of Scutellinia have been included in larger level studies (Perry et al. 2007). As a component of our broader work we have undertaken a molecular phylogenetic study and although this is not presented here in this regional mycota, it has helped to inform our decisions on the delimitation of species. The phylogeny will be presented as part of a larger study. 
Among the approximately 50 species recognized in Scutellinia (Schumacher 1988, 1990) four species have been recorded from Korea prior to work by the present authors: $S$. erinaceus (Schwein.) Kuntze (Cho \& Lee 2002), S. kerguelensis (Berk.) Kuntze (Park et al. 1994, Jung 1995), S. scutellata (L.) Lambotte (Lee \& Cho 1975, Jung 1995) and S. umbrorum (Fr.) Lambotte (Cho et al. 1997). Cho et al. (1997) had reported S. pseudoumbrarum J.Moravec, but this species is now considered a synonym of $S$. umbrorum (see Schumacher 1990). Only in the case of S. kerguelensis and S. scutellata (Jung 1995) did these earlier workers provide detailed information on morphological characters, such as shape and size of hairs and wall ornamentation of ascospores. Such features are important in identifying species; records that lack such information are considered questionable.

From 2001 to 2008 fieldwork was conducted in South Korea with a specific emphasis on the cup-fungi. Many Scutellinia specimens were collected from around the country by the first three authors. The main objective of this study is to document the Scutellinia species in Korea based on these extensive collections. Descriptions, taxonomic and a key are included.

\section{Materials and methods}

About one hundred Scutellinia specimens collected between 2001 and 2008 were examined and identified. Specimens were collected from many locations throughout South Korea. These were studied in fresh condition to observe color and macroscopic features and dried condition, primarily to observe and measure structures. Specimens are deposited in the Fungal Herbarium of Korea University (KUS-F). Microscopic examination was made from hand-free sections in water or $3 \% \mathrm{KOH}$ and subsequently stained in Lactofuchsin or Cotton Blue in lactic acid. Measurements were performed at $1000 \times$ for ascospores and at $100-400 \times$ for other structures. Size of ascospores are reported as maxima and minima in parentheses, and the mean plus and minus for the standard deviation of 50 matured spores.

To observe spore wall ornamentation Scanning Electron Microscopy (SEM) was performed on the following species: $S$. ahmadiopsis W.Y.Zhuang, S. badio-berbis (Berk. ex Cooke) Kuntze, $S$. colensoi Massee ex LeGal, S. olivascens (Cooke) Kuntze, S. scutellata and S. patagonica (Rehm) Gamundí. The quality of available material precluded S. jejuensis J.G.Han, Y.J.Choi \& H.D.Shin, S. jilinensis Z.H.Yu \& W.Y.Zhaung, S. nigrohirtula (Svr

ek) LeGal and S. setosa (Nees) Kuntze from SEM study. For SEM specimen holders with double-sided adhesive tape were placed in the middle of a Petri dish bottom that was lined with wet filter paper. Apothecia were hung upside down above the holders at the middle of a Petri dish cover. The Petri dish was sealed with Parafilm and incubated at $18^{\circ} \mathrm{C}$ for one or two days. After air-drying, the ascospores were coated with platinum with a Hitachi E-1010 ion sputter. The surface structure of spores was observed at $18 \mathrm{kV}$ and photographed with a Hitachi S-3500N scanning electron microscope. 
111 In the treatment that follows recognized species are arranged alphabetically. New records from

112 Korea are marked with an asterisk (*).

113

114 Taxonomy

115 * Scutellinia ahmadiopsis W.Y.Zhuang, Fung. Diversity 18: 216 (2005)

(FIGS. 1 A-D)

116

Apothecia sessile, 3-8(-15) $\mathrm{mm}$ diam, discoid, disc irregularly undulate to round, with an

117

indistinct margin covered by very short, pale brown hairs; hymenium orange or dull orange when

118 fresh. ECTAL EXCIPULUM of textura globulosa to textura angularis, individual cells $20-80 \mu \mathrm{m}$ diam, hyaline to subhyaline, elongated toward the margin. MEDULLARY EXCIPULUM of textura

120

121

122

123

124

125

126

127

128

129

130

131

132

133

134

135

136

137

138

139

140

141

142

143

144

145

146

147

intricata, hyaline. SUBHYMENIUM indistinct. HAIRS not differentiated, pale brown, mostly ventricose, slightly bent, 100-320 $\mu \mathrm{m}$ long, 10-22 $\mu \mathrm{m}$ wide, 2-6 septate, walls thick up to 3-5 $\mu \mathrm{m}$, apex pointed or sometimes obtuse, bases simple or bifurcate. Asci hyaline, cylindric, 8

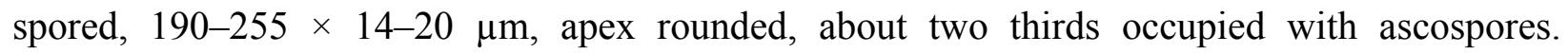
ASCOSPORES ellipsoid to broadly ellipsoidal, (18.5-)19.6-21.8(-23.5) (av. 20.7) $\mu \mathrm{m}$ long, (11)12.8-14.1(-14.5) (av. 13.5) $\mu \mathrm{m}$ wide, $1 / \mathrm{w}$ ratio (1.35-)1.46-1.62(-1.70) (av. 1.54), containing mostly one large guttule in dry material, but often two or many small guttules; wall ornamentation low and irregularly verrucose; warts irregular in shape and size, $0.3-1.2(-1.5) \mu \mathrm{m}$ wide, $0.2-0.6 \mu \mathrm{m}$ high, often interconnected; wall not loosening in heated lactic acid. PARAPHYSES filiform, straight, hyaline, 6-7 septate, 2-4 $\mu \mathrm{m}$ wide, not or branched 1-2 times in lower part, even with or slightly longer than the asci; apical cell clavate, 30-45 $\mu \mathrm{m}$ long, 6-10 $\mu \mathrm{m}$ wide.

Specimens examined. SOUTH KOREA: Pocheon, National Arboretum, 19 Jul 2001 (KUSF50040); as above, 24 Aug 2001 (50171); Pyeongchang, Korea Botanic Garden, 6 Jun 2002 (50534, 50535); Chuncheon, Haekgol, 28 Jun 2002 (50560); Gangneung, Eoheul-ri, 1 Jul 2002 (50586); Hongcheon, Experimental Forest of Kangwon National University, 23 Sept 2005 (50874); Guri, Donggureung, 12 Oct 2007 (51938).

Habitat. On damp rotting woods, branches or twigs

Notes. Based on undifferentiated short marginal hair, ellipsoidal to broadly ellipsoidal ascospores and verrucose wall ornamentation, the present material agrees well with $S$. ahmadiopsis (Zhuang 2005), although marginal hairs are longer in the Korean specimens (up to $320 \mu \mathrm{m}$ ) than in its original description from China (up to $205 \mu \mathrm{m}$ ). A similar species with short marginal hairs and low warts, S. hyalohirsuta W.Y.Zhuang, has recently been introduced (Zhuang \& Yang 2008), but this species could be distinguished from S. ahmadiopsis by broader ascospores (14.7-17.6 $\mu \mathrm{m})$ and more finely warted ascospore. Many morphological characteristics of this species are similar to S. superba (Velen.) LeGal that is recorded mainly from Europe. But, S. ahmadiopsis possesses spore walls that do not loosen in heated lactic acid; a clearly loosened wall is present in S. superba. Additionally, these species are found on different 
148

149

150

151

152

153

154

155

156

157

158

159

160

161

162

163

164

165

166

167

168

169

170

171

172

173

174

175

176

177

178

179

180

181

182

183

substrates; S. ahmadiopsis is collected on rotten woods or duff (Zhuang 2005, this work) and $S$. superba is found on sandy soil on the forest floor and along river beds (Schumacher 1990, Korf \& Zhuang 1991, Yao \& Spooner 1996, Hansen \& Knudsen 2000). Based on microverrucose wall ornamentation, this species is somewhat similar to $S$. kerguelensis, but the latter species differs by longer marginal hairs $(130-480 \mu \mathrm{m})$ and larger ascospores $(21.8-28.2 \times 14.4-21.8 \mu \mathrm{m})$.

* Scutellinia badio-berbis (Berk. ex Cooke) Kuntze, Revis. Gen. Pl. 2: 869 (1891) (FIGS. 1 E-H) APOTHECIA scattered to gregarious, sessile, discoid, 2-6(-10) $\mathrm{mm}$ diam, disc round or slightly undulate; hymenium orange when fresh, with a distinct margin covered by long and short hairs. ECTAL EXCIPULUM of textura globulosa to textura angularis, individual cells $25-75 \mu \mathrm{m}$ diam, subhyaline, outermost cells mostly smaller, 15-30 $\mu \mathrm{m}$ wide. MEDULLARY EXCIPULUM of textura intricata, hyphae 12-18 $\mu \mathrm{m}$ wide, individual cells ca. $200 \mu \mathrm{m}$ long, hyaline, thin-walled. SUBHYMENIUM of textura prismatica, individual cells 10-17.5 $\mu \mathrm{m}$ diam, hyaline, thin-walled. HAIRS clearly differentiated; marginal hairs stiff, brown to dark brown, of uneven length, 4001600(-2000) $\mu \mathrm{m}$ long, (20-)30-50 $\mu \mathrm{m}$ wide, (5-)13-25 septate, thick-walled of (4-)5-8 $\mu \mathrm{m}$, apex pointed or rarely blunt, with a bi-, tri- to multi-furcate rooting base; lateral hairs shorter than marginal hairs, less than $500 \mu \mathrm{m}$, paler brown than marginal hairs, apex pointed; hyphoid hairs hyaline, 1-2(-3) celled, less than $100 \mu \mathrm{m}$, with obtuse apex. Asci cylindric, 8-spored, 180$260 \times 13-15(-18) \mu \mathrm{m}$, about three fifths occupied with ascospores. AsCOSPORES ellipsoid, (16.0)18.8-21.6(-24.0) (av. 20.2) $\mu \mathrm{m}$ long, (9.5-)11.0-12.4(-13) (av. 11.7) $\mu \mathrm{m}$ wide, $1 / \mathrm{w}$ ratio (1.50)1.65-1.85(-1.95) (av. 1.75), with slightly pointed ends, containing one or two large and several small internal guttules; wall ornamentation clearly pustulo-cristate; warts $1.2-3.0(-4.0) \mu \mathrm{m}$ wide, $0.8-1.2(-2.4) \mu \mathrm{m}$ high, most prominent and protruding around the poles, often connected to neighbouring ones, formed short ridges; wall not loosening in heated lactic acid. PARAPHYSES filiform, straight, hyaline, 4-5 septate, 2.5-3.5 $\mu \mathrm{m}$ wide, simple or branched at the base, slightly exceeding the asci; apical cell spadiciform, not sinuous, 5.5-10 $\mu \mathrm{m}$ wide, often shorter than the lower cells, (18-)24-40 $\mu \mathrm{m}$ long.

Specimens examined. SOUTH KOREA: Jeju, Seogwipo, a mushroom farm near Hallasan National Park, 14 Aug 2001 (KUS-F50134, 50145, 50149); Gangneung, Eoheul-ri, Daegwanryeong Recreational Forest, 5 Oct 2001 (50293); as above, 19 Oct 2001 (50376), as above, 6 Jun 2002 (50539); Juju, Seogwipo, Yeongsil, 13 Sept 2002 (50671, 50674, 50676); Hongcheon, near Yeonhwa Temple, 23 Sept 2005 (50885); Danyang, Youngbuwon-ri, Sobaeksan National Park, 20 Oct 2005 (50955); Yeongju, Sobaeksan National Park, Oknyeobong Recreational Forest, 21 Oct 2005 (50968); Hongcheon, near Yeonhwa Temple, 16 Jun 2006 (51101); Namyangju, Jinjeop-eup, Gwangneung, 12 Aug 2006 (51240).

Habitat. On damp rotting wood 
184

185

186

187

188

189

190

191

192

193

194

195

196

197

198

199

200

201

202

203

204

205

206

207

208

209

210

211

212

213

214

215

216

217

218 219 F50643); Dongducheon, Mt. Soyo, 6 Sept 2002 (50649, 50653, 50655, 50657).

220 Habitat. On damp rotting wood

Notes. This is the first record in Korea of S. badio-berbis, a tropical to subtropical species with worldwide distribution excluding Europe. The long marginal hairs and ellipsoidal ascospores with large, coarsely pustulo-cristate sculpturing characterize this species. The Korean materials showed a minor difference from the description of Schumacher (1990) in possessing somewhat smaller asci $(180-260 \times 13-15(-18) \mu \mathrm{m} v s .230-280 \times 15-18.6 \mu \mathrm{m})$ and lower warts $(0.8-1.2(-$ 2.4) $v s$. up to $3.2 \mu \mathrm{m})$. Some earlier workers recorded slightly larger ascospores than we found and those reported by Schumacher (1990) of 18.2-23.2 × 9.6-13.2 $\mu \mathrm{m}$, e.g. $22-28 \times 14-17 \mu \mathrm{m}$ by Le Gal (1953), 19.2-25 × 11-14.4 $\mu \mathrm{m}$ by Gamundí (1975) and av. $23.2 \times 13.2 \mu \mathrm{m}$ by Kullman (1982). Some of these measurements may include the height of warts that are about 2 $\mu \mathrm{m}$ high.

* Scutellinia colensoi Massee ex Le Gal, Bull. Soc. Mycol. Fr. 83: 356 (1967) (FIGS. 1 I-L) APOTHECIA sessile, discoid, 2-5(-8) mm diam, disc round or slightly undulate, with a distinct margin covered with long, blackish hairs of uneven length; hymenium orange to red when fresh, but fading to brownish orange in dried specimens. ECTAL EXCIPULUM of textura globulosa to textura angularis, individual cells $25-120 \mu \mathrm{m}$ diam, towards the margin elongated, hyaline to subhyaline. Medullary EXCIPUlum of dense textura intricata, individual hyphae 5-12 $\mu \mathrm{m}$ wide. SUBHYMENIUM of densely packed mostly isodiametric cells, 5-10 $\mu \mathrm{m}$ wide. HAIRS clearly differentiated; marginal hairs stiff, brown to dark brown, uneven in length, 300-1700 $\mu \mathrm{m}$ long $\times$ 24-48 (av. 36) $\mu \mathrm{m}$ wide near the base, apex pointed, 10-20 septate, walls 3-5 $\mu \mathrm{m}$ thick, with a bi-, tri- to multi-furcate prominent base, individual rootlets relatively short and thin; lateral hairs shorter than marginal hairs, 120-350 $\mu \mathrm{m}$, paler than marginal hairs, often flexuous, with a bifurcated or unbranched base, apex pointed or obtuse; hyphoid hairs mostly 2-celled, mostly less than $100 \mu \mathrm{m}$ long, pale yellow or hyaline. Asci cylindric, 8-spored, 180-240 × 10-15 $\mu \mathrm{m}$, with a short base, apex rounded, about three fifths occupied by ascospores. AsCOSPORES ellipsoid, (16.0-)17.1-19.4(-20.0) (av. 18.3) $\mu \mathrm{m} \times(9.5-) 10.1-11.3(-12.0)($ av. 10.7) $\mu \mathrm{m}, 1 / \mathrm{w}$ ratio (1.50-)1.61-1.81(-2.00) (av. 1.71), with obtuse ends, containing one or two large internal guttules or several smaller ones; wall ornamentation clearly pustulo-cristate, warts large, up to $3.2 \mu \mathrm{m}$ wide, up to $1.2 \mu \mathrm{m}$ high, sometimes confluent to give a pseudo-reticulum; wall not loosening in heated lactic acid. PARAPHYSES filiform, straight, hyaline, 5-6 septate, $2.5-3.5 \mu \mathrm{m}$ wide, simple or 1-2 times branched from midpoint, slightly exceeding the asci, containing orange pigment granules throughout when fresh; apical cell spadiciform, lanceolate or slightly enlarged towards tip, sinuous, irregular in width, only slightly wider than other cells, 4-7(-8) $\mu \mathrm{m}$ $\times(20-) 30-50$ (av. 40) $\mu \mathrm{m}$.

18 Specimens examined. SOUTH KOREA: Pocheon, National Arboretum, 29 Aug 2002 (KUS- 
221

222

223

224

225

226

227

228

229

230

231

232

233

234

235

236

237

238

239

240

241

242

243

244

245

246

247

248

249

250

251

252

253

254

255

256

Notes. The long marginal hairs and conspicuous pustulo-cristate ornamentation with large warts characterize this species. The asci of the Korean specimens are smaller than those given by Schumacher $(1990)(210-280 \times 14-19 \mu \mathrm{m})$, but are similar to other records: $180-230 \times 11-15$ $\mu \mathrm{m}$ from Zhuang \& Wang (1998b) and 175-215 × 11-15 $\mu \mathrm{m}$ from Douanla-Meli \& Langer (2005). Among the ten Scutellinia species with this type of wall sculpturing S. colensoi is most similar to S. badio-berbis. Other species with this type of wall ornamentation are: S. badioberbis, S. balansae, S. colensoi, S. cubensis, S. erinaceus, S. cejpii, S. geneospora, S. inexpectata, S. jungneri and S. nigrohirtula. Previously, S. badio-berbis and S. colensoi often were confused because of their similar morphological characteristics, overlapping geographic distribution and their occurrence on damp rotting wood (Le Gal 1953, Gamundí 1975, Schumacher 1990), As a result, Kullman (1982) treated S. colensoi as a synonym of S. badioberbis. In the present study, on the contrary, S. badio-berbis is clearly different from S. colensoi by its more massive and higher warts on the ascospores. This is in agreement with previous findings by Otani (1971), Moravec (1978) and Schumacher (1990). It is the case that the width of the warts was too similar to distinguish between the two species. Additionally, the ascospore dimension of $S$. colensoi $(17.1-19.4 \times 10.1-11.3 \mu \mathrm{m})$ are also somewhat smaller than that of $S$. badio-berbis $(18.8-21.6 \times 11.0-12.4 \mu \mathrm{m})$ and are similar to measurements given by Schumacher (1990), 17.2-20.3 × 9.8-11.6 $\mu \mathrm{m}$ vs. 18.2-23.2 × 9.6-13.2 $\mu \mathrm{m}$. Le Gal (1953) and Schumacher (1990) say that $S$. colensoi has obtuse ellipsoidal spores rather than pointed ellipsoidal spores as in the latter species. In our study S. badio-berbis more often has pointed ellipsoidal spores than does $S$. colensoi, but these two ascospore shapes co-existed even in a single apothecium. Spore shape seems not to be a clear character to distinguish these species. The reports that $S$. colensoi has longer and thicker marginal hairs than S. badio-berbis (Le Gal 1953, Kullman 1982) could not be confirmed here since their size ranges varied according to specimens and often the measurements overlapped. Instead, we found that $S$. colensoi could be characterized by sinuous apical cells of paraphyses, which are also longer and narrower than those of S. badio-berbis. The height of warts on ascospores and shape of the apical cell of the paraphyses seem to be the most useful to differentiate the two species; these differences were constantly found among many specimens. Previously the morphology of paraphyses was not considered to be relevant for species delimitation of the Scutellinia. As a result, many morphological investigations have provided only the width and shape of apical cells without attributing any taxonomic value. However, the present study highlights the potential taxonomic importance of this character, which thus should be observed carefully and characteristics should be reported in species descriptions.

Scutellinia colensoi is widely distributed in subtropical to warm temperate regions. This is the first record from Korea. It seems to be widely distributed in Asian countries, including Japan, 
257 Pakistan, Thailand (Schumacher 1990), China (Zhuang \& Wang 1998a), and Russia (Bogacheva

258

259

260

261

262

263

264

265

266

267

268

269

270

271

272

273

274

275

276

277

278

279

280

281

282

283

284

285

286

287

288

289

290

291

292 $\&$ Kullman 2006) but has not been reported from North America.

Scutellinia jejuensis J.G.Han, Y.J.Choi, H.D.Shin, Mycotaxon 112: 48 (2010)

For a description of this recently described species the original publication (Han et al. 2010) should be consulted.

Specimen examined. SOUTH KOREA: Jeju, Hallasan National Park, near Mulchat-oreum, 5 Nov 2008 (KUS-F52411).

Habitat. on shaded, damp soil

Notes. Han et al. (2010) introduced this species that has subglobose to globose ascospores and aculeolate-reticulate ornamentation. Most of the Scutellinia species in Asia have ellipsoid spores (Otani 1971, Kaushal et al. 1983, Zhuang 1989, 1994, 1997, 1998); this is the only species with subglobose spores so far collected in South Korea. Scutellinia jejuensis and S. sinensis M.H.Liu from China (Liu \& Peng 1996) are the confirmed species with subglobose to globose spores in Asia.

\section{* Scutellinia jilinensis Z.H.Yu \& W.Y.Zhuang, Mycotaxon 75: 404 (2000)}

APOTHECIA scattered to gregarious, sessile, discoid, 1.5-6(-8) $\mathrm{mm}$ diam, disc round or slightly undulate, with a distinct margin covered by long marginal hairs; hymenium orange to red when fresh but often brown in dried specimens. ECTAL EXCIPULUM of textura globulosa to textura angularis, individual cells $30-70 \mu \mathrm{m}$ diam, subhyaline to pale yellow, outermost cells mostly smaller and longer, 15-30 $\mu \mathrm{m}$ wide. Medullary EXCIPUlum of textura intricata. SUBHYMENIUM of textura prismatica, individual cells 10-20 $\mu \mathrm{m}$ diam, hyaline, thin-walled. HAIRS clearly differentiated; marginal hairs stiff, brown to dark brown, of uneven length, 300$1600 \mu \mathrm{m}$ long, (20-)30-50 $\mu \mathrm{m}$ wide, 3-8(-13) septate, thick walls, (4-)5-8 $\mu \mathrm{m}$, apex pointed or rarely blunt, with a (bi-)tri- to multifurcate rooting base; lateral hairs shorter than marginal hairs, mostly $150-360 \mu \mathrm{m}$, paler brown than marginal hairs, with a simple or bifurcate rooting base, apex pointed; hyphoid hairs hyaline to pale yellow, 1-2-celled, less than $100 \mu \mathrm{m}$ long, 14-23 $\mu \mathrm{m}$ wide. ASCI cylindric, 8-spored, 200-280 × 12-18 $\mu \mathrm{m}$, apex mostly rounded, about three fifths occupied with ascospores. AsCOSPORES broadly ellipsoid to ellipsoid, (14-)15.6-18.0(-21) (av. 16.8) $\mu \mathrm{m}$ long, (10-)10.2-11.6(-12) (av. 10.9) $\mu \mathrm{m}$ wide, excluding the height of warts, $1 / \mathrm{w}$ ratio (1.40-)1.47-1.64(-1.80) (av. 1.55), containing mostly one large but rarely two or several small internal guttules; wall ornamentation pustulo-cristate or partially reticulated; warts large, variable in size and shape, 1-2.5(-3.5) $\mu \mathrm{m}$ wide, $0.8-1.2(-1.5) \mu \mathrm{m}$ high, isolated or confluent, often forming short ridges to give a pseudoreticulate pattern; wall not loosening in heated lactic acid. PARAPHYSES filiform, straight, hyaline, 4-5 septate, 2.5-4.0 $\mu \mathrm{m}$ wide, simple or branched at the 
293

294

295

296

297

298

299

300

301

302

303

304

305

306

307

308

309

310

311

312

313

314

315

316

317

318

319

320

321

322

323

324

325

326

327

328

329

base, slightly exceeding the asci; apical cell enlarged to (6-)8-11 $\mu \mathrm{m}$ wide, irregular in width, often shorter than the cells below, 16-35 $\mu \mathrm{m}$ long.

Specimens examined. SOUTH KOREA: Gangneung, Eoheul-ri, 1 Jul 2002 (KUS-F50576); Dongducheon, Mt. Soyo, 6 Sept 2002 (50659); Jeju, Seogwipo, Yeongsil, 13 Oct 2002 (50675).

\section{Habitat. On damp rotting wood}

Notes. The three Korean collections listed here are close to $S$. badio-berbis having long marginal hairs, broadly ellipsoid ascospores with pustulo-cristate or partially reticulate ornamentation, but they have smaller ascospores $(15.6-18.0 \times 10.2-11.6 v s .18 .8-21.6 \times 11.0-12.4 \mu \mathrm{m})$ than that species. Five Scutellinia species have similar morphological characteristics to specimens referred here to S. jilinensis. Scutellinia chiangmaiensis T.Schumach. and S. cubensis have broader ascospores (15.3-18.0 × 11.0-13.0 and 15.6-18.5 × 11.2-14.4 $\mu \mathrm{m})$ and shorter marginal hair (up to 950 and $600-1100 \mu \mathrm{m}$ ) (Schumacher 1990); S. pennsylvanica is distinguished by more conspicuous reticulate pattern on ascospore walls and somewhat larger ascospores (16.2-22.8 $\times$ 11.2-13.6 $\mu \mathrm{m}$ ) (Schumacher 1990). The wall ornamentation and size of ascospores are close to $S$. fujianensis J.Z.Cao \&J.Moravec (Cao \& Moravec 1988), but the latter species differs from the present specimens in its shorter and narrower marginal hairs of $130-540(-700) \times 10-27 \mu \mathrm{m}$, higher warts of $2-3.7(-4.5) \mu \mathrm{m}$ and in its occurrence on soil. The morphological characteristics of the present species agree well with S. jilinensis (Yu et al. 2000), although its ascospores are slight broader (10.2-11.6 vs. 10-12.7 $\mu \mathrm{m})$ and the warts are more interconnected. Scutellinia jilinensis was originally recorded from the Changbai Mountains, also known as the Baekdu Mountains in Korea, on the border between North Korea and China. It was also collected on rotting woods like the Korean specimens. This is the first record of it from Korea, and it seems to be distributed widely in East Asia, as referred to by Zhuang (2005).

\section{* Scutellinia nigrohirtula (Svrček) Le Gal, Bull. Soc. Mycol. Fr. 80: 123 (1964)}

ApотнесіA sessile, discoid, 3-10(-15) $\mathrm{mm}$ diam, disc round or undulate, with a distinct margin densely clothed with dark brown hairs; hymenium reddish to orange when fresh. ECTAL EXCIPULUM of textura globulosa to textura angularis, individual cells 30-100 $\mu \mathrm{m}$ diam, towards the margin elongated. Medullary EXCIPUlum of textura intricata, hyphae 6-12 $\mu \mathrm{m}$ wide, hyaline, thin-walled. SUBHYMENIUM of densely packed, angular, short-celled hyphae. HAIRS not differentiated; marginal hairs stiff, mostly straight but rarely slightly flexuous, ventricose, brown to pale brown, 200-420 $\mu \mathrm{m}$ long, 18-30 $\mu \mathrm{m}$ wide, apex pointed or rarely obtuse, 3-6 septate, thick-walled of up to $8 \mu \mathrm{m}$, with a simple or bifurcate base; lateral hairs shorter than marginal hairs, often flexuous, apex pointed or rarely obtuse, with mostly unbranched rooting bases; hyphoid hairs were observed. AscI cylindric, hyaline, 8-spored, (160-)200-260 × 18-23(-28) $\mu \mathrm{m}$, apex slightly rounded, about two thirds occupied with ascospores. AsCOSPORES hyaline, ellipsoid to broadly ellipsoidal, (20.0-)21.7-26.3(-29.0) (av. 24.0) $\mu \mathrm{m}$ long, (13.5-)14.2-16.0(- 
330

331

332

333

334

335

336

337

338

339

340

341

342

343

344

345

346

347

348

349

350

351

352

353

354

355

356

357

358

359

360

361

362

363

364

365

366

16.5) (av. 15.1) $\mu \mathrm{m}$ wide, $\mathrm{l} / \mathrm{w}$ ratio (1.35-)1.46-1.67(-1.80) (av. 1.57), containing one or two large guttules; wall ornamentation verrucose or low pustulo-cristate, composed of small warts, irregularly distributed, often confluent and forming sinuate line, commonly $0.4-0.8 \mu \mathrm{m}$ wide but when interconnected up to $1.5 \mu \mathrm{m}$, less than $0.4 \mu \mathrm{m}$ high; wall not loosening in heated lactic acid. PARAPHYSES filiform, straight, hyaline, 5-6 septate, 3-4 $\mu \mathrm{m}$ wide, simple or sometimes branched below, slightly exceeding the asci; apical cell clavate, enlarged to $8-12 \mu \mathrm{m}$ wide, 30 $40 \mu \mathrm{m}$ long.

Specimen examined. SOUTH KOREA: Gangneung, Eoheul-ri, 19 Oct 2001 (KUS-F50377); as above, 1 Jul 2002 (50584).

Habitat. On damp rotting woods

Notes. This is the first record of this species from Korea. The undifferentiated short marginal hairs and ellipsoidal to broadly ellipsoidal ascospores with verrucose ornamentation are in agreement with S. nigrohirtula as described by Gamundí (1975), Hirsch (1985) and Schumacher (1990). The short hairs and large ascospores of S. nigrohirtula are most like S. kerguelensis, but it is easily distinguishable by a higher $1 / \mathrm{w}$ ratio of ascospores and somewhat visible spore sculpturing in profile. S. nigrohirtula has ellipsoid ascospores up to $17 \mu \mathrm{m}$ wide $(13.8-16.6 \mu \mathrm{m}$ in Schumacher (1990), 14-17 $\mu \mathrm{m}$ in Zhuang (1994) and 14-16.5 $\mu \mathrm{m}$ in Hansen \& Knudsen (2000)), while $S$. kerguelensis has broadly ellipsoid to subglobose spores up to 20-22 $\mu \mathrm{m}$ (Schumacher 1979, 1990, Yao \& Spooner 1996, Hansen \& Knudsen 2000). Scutellinia nigrohirtula is often found in boreo-temperate regions of Europe and South America (Schumacher 1990). The records from Japan (Schumacher 1990) and China (Zhuang 1994, Zhuang \& Yang 2008), as well as Korea (this study) indicate that this species is also commonly distributed in Asia.

* Scutellinia aff. olivascens (Cooke) Kuntze, Rev. Gen. Pl. 2: 869 (1891)

(Figs. 1 M-P)

APOTHECIA sessile, 3-10(-20) mm diam, discoid, disc round or irregular undulate, with a distinct margin covered by short blackish brown hairs; hymenium orange to red when fresh. ECTAL EXCIPULUM of textura globulosa to textura angularis, individual cells 30-110 $\mu \mathrm{m}$ diam. Medullary eXCIPUlum of textura intricata, hyphae 5-8(-11) $\mu \mathrm{m}$ wide, hyaline. SubHYMENIUM indistinct. HAIRS not differentiated, stiff, densely crowded, brown, 180-480(-850) $\mu \mathrm{m}$ long, 12 $30(-35) \mu \mathrm{m}$ wide, 3-10 septate, with walls 3-5 $\mu \mathrm{m}$ thick, apex pointed or obtuse, base bi- or trifurcate, distinct, mostly unforked, deeply rooting. AsCI hyaline, cylindric, 8-spored, 200-280 $\times$ 14-20 $\mu \mathrm{m}$, apex slightly flattened, about three fifths occupied with ascospores. ASCOSPORES ellipsoid, with slightly narrow ends, (20.0-)21.2-24.5(-27.5) (av. 22.8) $\mu \mathrm{m}$ long, (12.0-)12.514.5(-16.0) (av. 13.5) $\mu \mathrm{m}$ wide, $1 / \mathrm{w}$ ratio (1.45-)1.62-1.83(-2.00) (av. 1.73), containing mostly one or two large but rarely numerous small guttules; wall ornamentation low and irregularly verrucose or pustulo-cristate; warts irregularly distributed, often confluent and merged, forming 
367

368

369

370

371

372

373

374

375

376

377

378

379

380

381

382

383

384

385

386

387

388

389

390

391

392

393

394

395

396

397

398

399

400

401

402

403

crests, variable in shape and size, $0.4-1.0 \mu \mathrm{m}$ wide, $0.4-0.6(-1.0) \mu \mathrm{m}$ high; wall not loosening in heated lactic acid. PARAPHYSES filiform, straight, hyaline, 5-6 septate, 2.5-4 $\mu \mathrm{m}$ wide, simple or branched at the base, slightly exceeding the asci; apical cell enlarged, clearly clavate, $40-55 \mu \mathrm{m}$ long, 8-10(-12) $\mu \mathrm{m}$ wide.

Specimens examined. SOUTH KOREA: Pyeongchang, Yongpyeong-myeon, Mt. Gaebang, 11 Jul 2002 (KUS-F50624, 50627); Hoengseong, Mt. Cheongtae, 11 Jul 2002 (50625); Hongcheon, near Yeonhwa Temple, 11 Jun 2007 (51627).

Habitat. On damp rotting wood

Notes. This is the first record of S. olivascens in Korea. The short hairs and large ascospores are similar to $S$. nigrohirtula and $S$. kerguelensis, although it has a higher 1/w ratio of ascospores. Additionally, S. olivascens is easily distinguished from these two species by the possession of rare longer hairs (up to $850 \mu \mathrm{m}$ ) and somewhat more visible spore sculpturing. Schumacher (1990) and Hansen \& Knudsen (2000) noted that broad marginal hairs to 45-50 $\mu \mathrm{m}$ could characterize this species, but the Korean specimens showed narrower ones (up to $35 \mu \mathrm{m}$ ). This range fits well with the descriptions of $S$. ampullacea and $S$. lusatiae, which were synonymised under S. olivascens by Schumacher (1990); for the former species 22-36 $\mu \mathrm{m}$ (Le Gal 1966) and

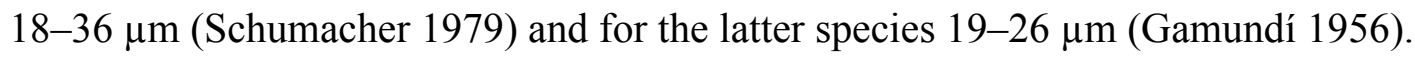

\section{* Scutellinia orientalis, Y.J.Choi, H.D.Shin \& Pfister, sp. nov. $\quad$ (FIGS. 2)} MycoBank MB 801278

Etymology. This name refers to biogeographical region, Korea and possibly China and Mongolia where the fungus was collected.

APOTHECIA gregarious to scattered, sessile, discoid, 2-5(-7) mm diam, disc rounded or slightly undulated with a distinct margin covered by blackish brown hairs which are stretched inward and outward, hymenium orange to reddish orange. ECTAL EXCIPULUM of textura globulosa to textura angularis, individual cells 30-150 $\mu \mathrm{m}$ diam, hyaline to subhyaline. MEdullary EXCIPULUM of textura intricata, hyaline, thin-walled. SUBHYMENIUM of textura prismatica. HAIRS slightly differentiated; marginal hairs stiff, brown to dark brown, of uneven length of (280-)480-1000(1500) $\mu \mathrm{m}$ long, 20-35(-42) $\mu \mathrm{m}$ wide, broader at base, thick-walled, 7.5-10 $\mu \mathrm{m}, 11-20(-32)$ septate, apex pointed, with a bi-, tri- to multifurcate base; lateral hairs shorter, 140-300 $\mu \mathrm{m}$ long, 15-20 $\mu \mathrm{m}$ wide, mostly straight, apex pointed, with mostly bifurcate, but rarely unbranched or trifurcate rooting base. ASCI cylindric, 8-spored, apex slightly flattened, 180-220 × 13-18 $\mu \mathrm{m}$, about two thirds occupied with ascospores. AsCOSPORES broadly ellipsoid to ellipsoid, (16)16.9-19.3(-21) (av. 18.1) $\mu \mathrm{m}$ long, (10.5-)11.4-12.6(-13.0) (av. 12.0) $\mu \mathrm{m}$ wide, $1 / \mathrm{w}$ ratio (1.35-)1.44-1.58(-1.65) (av. 1.51), containing a single large or several small internal guttules; wall ornamentation tuberculate; warts irregularly and densely distributed on the surface, $0.3-0.8$ $\mu \mathrm{m}$ wide, 0.2-0.4(-0.6) $\mu \mathrm{m}$ high, rounded, isolated but often inter-connected between 
404

405

406

407

408

409

410

411

412

413

414

415

416

417

418

419

420

421

422

423

424

425

426

427

428

429

430

431

432

433

434

435

436

437

438

439

440

neighboured ones, especially in immature spores. PARAPHYSES filiform, straight, hyaline, 2.5-4 $\mu \mathrm{m}$ wide, 5-6 septate, simple or branched at the base, exceptionally branched in upper part; apical cell clavate, $26-54 \mu \mathrm{m}$ long, $6.5-9 \mu \mathrm{m}$ wide.

Holotype. SOUTH KOREA, Pocheon, National Arboretum, on damp rotting wood, 27 Sept 2001, Y.J. Choi \& H.D. Shin (KUS-F50264)

Specimens examined. As above, 29 Aug 2002, Y.J. Choi \& H.D. Shin (KUS-F50641).

Habitat. On damp rotten wood

Notes. Regarding the tuberculate wall ornamentation of ascospores and uneven length of marginal hairs, this species is most close to S. subhirtella Svr

ek and S. patagonica. By having much longer and wider marginal hairs with more septa (FIG. 2 C\&D) and multi-rooted base (FIG. 2 E) the Korea specimens of $S$. orientalis can be easily differentiated from these two species based on the marginal hairs of 150-600 $\times 15-30 \mu \mathrm{m}$ (Svrček 1971) and 200-1050 × 15-48 $\mu \mathrm{m}$ (Schumacher 1990), respectively. Additionally, the ascospores are somewhat smaller, and the warts are more often connected (FIG. 2 F-J; see Fig. 1. S\&T for $S$. patagonica). Substrate differences also offer evidence for discriminating between $S$. subhirtella and the present species. Scutellinia subhirtella is mostly found on humid soil or very rarely on plant or surrounding wood debris (Schumacher 1979, 1990, Hansen \& Knudsen 2000), but the collections of $S$. orientalis were made on damp wood, that was not in direct contact with the soil. Sequence comparisons show that $S$. orientalis and two specimens of $S$. subhirtella from Europe are phylogenetically distant thus adding support for the recognition of this species. The specimens used by us in phylogenetic comparisons and identified as S. subhirtella were those included in Perry et al. (2007) and one that was from TAAM redetermined by us as $S$. subhirtella.

In China and Mongolia, a few studies (Zhuang 1994, 1997, Zhuang \& Wang 1998b, Yu et al. 2000) found several $S$. subhirtella-like specimens occurring on the rotten wood. Interestingly, Zhuang (1994) and Yu et al. (2000) also noted that some specimens possess exceptionally long marginal hairs (up to $1600 \mu \mathrm{m}$ ), that are much longer than other Scutellinia species with tuberculated ascospores and those of $S$. subhirtella, but are similar to S. orientalis. Yu et al. (2000) temporarily treated it as S. cfr. subhirtella. The Chinese and Mongolian collections seem to be identical to those from Korea.

* Scutellinia aff. patagonica (Rehm) Gamundí, Lilloa 30: 318 (1960)

(FIGS. 1 Q-T)

APOTHECIA scattered to gregarious, sessile, discoid, 3-8(-14) $\mathrm{mm}$ diam, disc round or slightly undulate, with a distinct margin densely clothed by blackish brown hairs of uneven length; hymenium orange or reddish orange when fresh. ECTAL EXCIPULUM of textura globulosa to textura angularis, individual cells 45-130 $\mu \mathrm{m}$ diam, towards the margin elongated, outer most cells up to $35 \mu \mathrm{m}$ with hyaline walls. MEDULLARY EXCIPULUM of densely interwoven textura 
441

442

443

444

445

446

447

448

449

450

451

452

453

454

455

456

457

458

459

460

461

462

463

464

465

466

467

468

469

470

471

472

473

474

475

476

477

intricata, hyphae 6-9 $\mu \mathrm{m}$ wide, hyaline, thin-walled. SUBHYMENIUM of dense textura prismatica. HAIRS not or slightly differentiated; marginal hairs stiff or slightly flexuous, ventricose to broad at base, dark brown to brown, uneven 150-800(-1000) $\mu \mathrm{m}$ long, 20-40(-45) $\mu \mathrm{m}$ wide, apex pointed or rarely blunt, 1-6 septate, thick-walled of 3.5-6 $\mu \mathrm{m}$, with mostly a bifurcate, prominent deeply rooting base; lateral hairs shorter than marginal hairs, 80-150(-300) $\mu \mathrm{m}$, ventricose, flexuous, 16-28 $\mu \mathrm{m}$ wide, apex pointed or rarely blunt, with mostly unbranched but rarely bifurcate bases. AsCI cylindric, 8-spored, (190-)220-260 × (14-)16-20 $\mu \mathrm{m}$, apex rounded, about three fifths occupied with ascospores. AsCOSPORES ellipsoid to broadly ellipsoid, (17.5)18.7-21.3(-23.5) (av. 20) $\mu \mathrm{m}$ long, (11-)11.6-13.5(-14.5) (av. 12.8) $\mu \mathrm{m}$ wide, $1 / \mathrm{w}$ ratio (1.35)1.50-1.67(-1.75) (av. 1.59), containing 1-2 large or several small guttules; wall ornamentation tuberculate; warts evenly distributed on the spore surface but variable in size $0.4-1.0(-2.0) \mu \mathrm{m}$ wide, $0.2-1.2 \mu \mathrm{m}$ high, mostly isolated but rarely connected between neighboured ones when ascospores are collapsed; wall not loosening in heated lactic acid. PARAPHYSES filiform, straight, hyaline, 5-6 septate, 3-4 $\mu \mathrm{m}$ wide, containing orange or yellowish orange pigment granules throughout when fresh, simple or sometimes branched below, slightly exceeding the asci; apical cell clavate, $20-46 \mu \mathrm{m}$ long, $7-10 \mu \mathrm{m}$ wide.

Specimens examined. SOUTH KOREA: Donghae, Cheongok-dong, near Donghae Gymnasium, 29 Aug 2001 (KUS-F50193); as above, 20 Oct 2001 (50383); as above, 7 Jun 2002 (50547); as above, 30 Aug 2002 (50646); Chungju, Sangmo-myon, 13 Jun 2002 (50558).

Habitat. On mostly humid soil but very rarely on rotten wood in areas of fruiting.

Notes. Scutellinia patagonica is mainly recognized by medium sized rooting hairs, broadly ellipsoidal ascospores, distinctly tuberculate ornamentation and rounded to angular warts on the ascospore wall surface (Schumacher 1979 1990). Morphological characteristics of the Korean specimens are mostly in agreement with other descriptions of this species, but the ascospores (av. $12.8 \mu \mathrm{m})$ are somewhat narrower, 13.4-18.5 $\mu \mathrm{m}$ in Schumacher (1990), 14.4-18.6 $\mu \mathrm{m}$ in (Gamundí 1975) and 13.8-18.5 $\mu \mathrm{m}$ in Hansen \& Knudsen (2000). The ellipsoidal ascospores are the most close in size to those of S. subhirtella, another tuberculate- walled species. The spores of that species are 12-14(-15) $\mu \mathrm{m}$ wide in Svrček (1971) and 12.0-14.8 $\mu \mathrm{m}$ in Schumacher (1990). Variable sized warts (generally $0.8 \mu \mathrm{m}$, but occasionally $2.0 \mu \mathrm{m}$ wide), a typical character of S. patagonica, were often observed in the Korean specimens (see Fig. 1. S \& T). This is quite different than S. subhirtella that has even small warts usually less than $1.2 \mu \mathrm{m}$ wide. The Korean specimens might be treated an undescribed species, but we treat it here as a member of a complex of taxa around $S$. patagonica. Our expanded molecular phylogenetic study of Scutellinia world-wide (in prep.) included specimens identified as S. patagonica by Schumacher. The collections reported here from Korea are most close to those collections. The exact identities of these taxa remain to be fully resolved. 
478 Scutellinia scutellata (L.) Lambotte, Fl. Mycol. Belge, Suppl. 1: 299 (1887)

(FIGS. 1 U-X)

479 ApOTHECIA scattered to gregarious, sessile, 2-10(-17) $\mathrm{mm}$ diam, discoid or slightly concave 480 with a distinct margin, disc mostly round but sometimes undulate at the margin, densely covered

481

482

483

484

485

486

487

488

489

490

491

492

493

494

495

496

497

498

499

500

501

502

503

504

505

506

507

508

509

510

511

512

513

514 with brownish black hairs of uneven length; hymenium orange or reddish orange when fresh. ECTAL EXCIPULUM of textura globulosa to textura angularis, cells 20-95 $\mu \mathrm{m}$ diam, toward the margin and in the outermost excipulum becoming elongated and clavate with hyaline to subhyaline walls. Medullary EXCIPUlum of dense textura intricata, cells 5-13 $\mu \mathrm{m}$ wide, hyaline, thin-walled. SUBHYMENIUM indistinct. HAIRS clearly differentiated; marginal hairs stiff, rarely bent, brown to dark brown, of uneven length, 400-1000(-1800) $\mu \mathrm{m}$ long, $22-45 \mu \mathrm{m}$ wide, broader toward the base, apex pointed or rarely blunt, 8-15(-24) septate, thick-walled of 3.5-7.5 $\mu \mathrm{m}$, with mostly a bi- or trifurcate base; lateral hairs shorter than marginal hairs, flexuous, paler brown or hyaline, 100-560 $\mu \mathrm{m}$ long, 12-26 $\mu \mathrm{m}$ wide, often constricted at the septa, apex pointed or sometimes blunt, base mostly unbranched but rarely bi-trifurcate; superficial hairs interspersed among the marginal hairs, variable in shape, clavate or bulbous, pale yellowish to hyaline, 30$100 \mu \mathrm{m}$ long, 0-2 septate, apex rounded, with simple base. Asci cylindric, 8-spored, (160-)200$240 \times 12-15(-18) \mu \mathrm{m}$, apex somewhat flattened, about two thirds occupied with ascospores. ASCOSPORES ellipsoid, variable in shape and size, (16.5-)17.4-20.2(-24) (av. 18.8) $\mu \mathrm{m}$ long, (10.4-)10.7-12.2(-14) (av. 11.5) $\mu \mathrm{m}$ wide, 1/w ratio (1.45-)1.53-1.70(-1.75) (av. 1.62), with obtuse to pointed ends, containing one or two large or several small guttules; spore sculpturing composed of minute verrucose warts, $0.2-0.8(-1.2) \mu \mathrm{m}$ wide, mostly less than $0.5 \mu \mathrm{m}$ high, often confluent, forming an incomplete reticulate; wall not loosening in heated lactic acid. PARAPHYSES filiform, straight, hyaline, 5-6 septate, 2.5-3 $\mu \mathrm{m}$ wide, containing orange or yellowish orange pigment granules throughout when fresh, simple or rarely branched at the base, slightly exceeding the asci; apical cell clavate, 7-10 $\mu \mathrm{m}$ wide, generally shorter than cells below, (16-)25-40 $\mu \mathrm{m}$ long.

Specimens examined. SOUTH KOREA: Gangneung, Eoheul-ri, Daegwanryeong Recreational Forest, 6 Jun 2002 (KUS-F 50543); Gangneung, Eoheul-ri, 1 Jul 2002 (50577, 50580, 50590); Pocheon, National Arboretum, 24 Jun 2002 (50394); as above, 8 May 2002 (50494); as above, 4 Jul 2002 (50602); Nonsan, Gyeryongsan National Park, near Gab Temple, 17 May 2002 (50519); Wonju, Chiaksan Natioanl Park, 3 Jun 2002 (50521, 50522, 50523); as above, 27 Aug 2004 (50722); as above, 30 Sept 2005 (50902); Pyeongchang, Korean Botanic Garden, 6 Jun 2002 (50533); Pyeongchang, Yongpyeong-myeon, Mt. Gaebang, 11 Jul 2002 (50604, 50626); Gangneung, Eoheul-ri, 6 Jun 2002 (50542); as above, 6 Jun 2002 (50546); as above, 1 Jul 2002 (50579, 50581, 50591, 50592); Gangneung, Eoheul-ri, Daegwanryeong Recreational Forest, 7 Jun 2002 (50548); Hongcheon, Hwajeon-ri, 24 Sept 2005 (50893); Hoengseong, Hoengseong Recreational Forest, 22 Jun 2006 (51122); Inje, Seoraksan National Park, near Baekdam Temple, 28 Sept 2006 (51405); Chuncheon, Goeun-ri, 11 Nov 2005 (50976). 
Habitat. on damp rotting wood

516 Notes. Lee \& Cho (1975) and Jung (1995) previously recorded this species in Korea. The long

517 marginal hairs and the small ellipsoidal ascospores with verrucose ornamentation characterize

518 this species. The morphological characteristics, geographic distribution and substrates are too

519 similar to $S$. crinita to separate them by the species boundaries of Schumacher (1990).

520 Previously, the species delimitation has been highly controversial among various authors

521 (Denison 1959, Le Gal 1966, Svrček 1971, Moravec 1978, Kullman 1982, Schumacher 1990,

522 Korf \& Zhuang 1991, Zhuang 1994). Later Yao \& Spooner (1996) suggested that S. crinita

523 should be considered a synonym of $S$. scutellata. In the Korean collections, the ascospores with

524 broadly rounded ends or slightly pointed ends were simultaneously observed in a single

525 apothecium, although it believed that this character serves to differentiate $S$. scutellata and $S$.

526 crinita.

527 Among about a hundred collections examined, 31 specimens are morphologically similar to $S$.

528 scutellata, suggesting it is evidently common all over South Korea, but within them, an

529 infraspecific morphological variation was found. Five specimens (50543, 50577, 50580, 50590,

530 50626) possess many superficial brown to yellowish hairs and thick wall of 3.5-4 $\mu \mathrm{m}$, but in

531 remaining specimens such hairs are rarely present and walls are thin, less than $2 \mu \mathrm{m}$. Also, under

532 the light microscope, somewhat higher warts of ascospores could be also discerned the five

533 collections from other specimens with minutely warted ascospores. Interestingly, a specimen

534 KUS-F50519, has remarkably large apothecia of 5-12(-20) $\mathrm{mm}$ diam, although other

535 morphological characteristics agree with $S$. scutellata. We treat all Korean specimens at least

536 temporarily as members of the $S$. scutellata complex.

537

538

* Scutellinia setosa (Nees) Kuntze, Rev. Gen. Pl. 2: 869 (1891)

539

APOTHECIA sessile, gregarious, discoid, 1-2(-3) mm diam, disc round, with an indistinct margin

540 covered by short, dark brown hairs; hymenium light orange to yellowish when fresh. ECTAL

541 EXCIPULUM of textura globulosa to angularis, individual cells $20-80 \mu \mathrm{m}$ diam, hyaline to subhyaline, elongated toward the margin. MEDULLARY EXCIPULUM of textura intricata, hyaline.

543 SubHYMENIUM thin, distinct. HAIRS not differentiated, densely crowded, mostly straight, brown 544 to dark brown, (200-)400-800(-1000) $\mu \mathrm{m}$ long, 18-32 $\mu \mathrm{m}$ wide, 3-6 septate, thick-walled of $5454.5-7(-8) \mu \mathrm{m}$, apex pointed or sometimes obtuse, with a bi- to multi-furcate base. Ascr hyaline, 546 cylindric, 8-spored, 130-230 $\times(10-) 12-16 \mu \mathrm{m}$, apex rounded, with short base. AsCOSPORES 547 ellipsoid to oblong, (17.0-)18.1-20(-22) (av. 19.1) $\mu \mathrm{m}$ long, (9-)10.0-12.1(-13.5) (av. 11.1) $\mu \mathrm{m}$ 548 wide, $1 / \mathrm{w}$ ratio (1.50-)1.60-1.75(-1.80) (av. 1.67), containing many small guttules; ascospore 549 walls smooth; wall not loosening in heated lactic acid. PARAPHYSES filiform, straight, hyaline, 45506 septate, 2-3 $\mu \mathrm{m}$ wide, not or branched 1-2 times in lower part, even or slightly longer than the asci; apical cell very slightly clavate, $4-7(-8) \mu \mathrm{m}$ wide, $30-52 \mu \mathrm{m}$ long. 
552

553

554

555

556

557

558

559

560

561

562

563

564

565

566

567

568

569

570

571

572

\section{3}

574

575

576

577

578

579

580

581

582

583

584

585

586

587

588

Specimen examined. SOUTH KOREA: Gangneung, Eoheul-ri, 19 Oct 2001 (KUS-F50363).

Habitat. On damp rotting wood

Notes. This species is easily recognized by small apothecia gregariously distributed on damp rotting wood and the smooth ascospore walls. The Korean specimen is well in agreement with a description of S. setosa by Schumacher (1990). This species was often regarded to be identical with S. erinaceus (Schwein.) Kuntze or S. setosissima LeGal. Earlier authors (Denison 1959, Svrček 1971, 1981) wrongly used the name S. erinaceus for the specimens with smooth ascospores, possibly representing S. setosa, as LeGal (1966, 1968) and Schumacher (1990) pointed out that $S$. erinaceus has a coarsely verrucose-spored taxon. Scutellinia setosissima appears smooth under optic microscopy, but this species indeed has minutely verrucose ascospores when they are observed under SEM (Schumacher 1990).

During studies between 2001 and 2008, this species only was collected once; thus, it seems to be rare in Korea. The presence of S. setosa in Asian regions has not been confirmed. When Zhuang (1994) examined the specimens referred to this species collected from China, she found it to be different than S. setosa s.str. from North America because of the minute makings on ascospore surface. The collections were later treated as a new species, S. sinosetosa (Zhuang \& Wang 1998b). To verify our identification, a sequence comparison of rDNA was performed to compare the Korean and North American specimens. This has supported the identity of the Korean specimens as $S$. setosa. Therefore, this is considered new to Asia.

\section{Key to the species of the genus Scutellinia in Korea}

1. Ascospores with smooth wall....................................................... Setosa

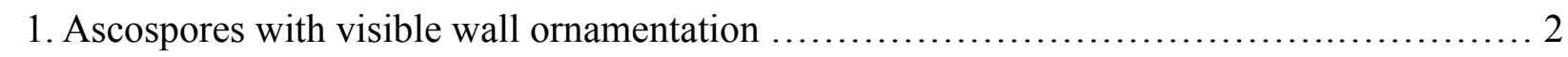

2. Ascospores subglobose to globose, with aculeolate-reticulate ornamentation ... S. jejuensis

2. Ascospores ellipsoidal to broadly ellipsoidal, with confluent or tuberculate ornamentation ... 3

3. Marginal hairs often more than $800 \mu \mathrm{m}$ long, differentiated from lateral hairs 4

3. Marginal hairs less than $800 \mu \mathrm{m}$ long, not differentiated from lateral hairs 7

4. Wall ornamentation tuberculate; warts mostly isolated but rarely interconnected ..... S. orientalis

4. Wall ornamentation verrucose or pustule-cristate, warts often confluent 5

5. Warts on wall surface less than $1.2 \mu \mathrm{m}$ high S. scutellata complex

5. Warts on wall surface more than $1.2 \mu \mathrm{m}$ high 6

6. Ascospores broadly ellipsoidal, less than $18 \times 11 \mu \mathrm{m}$; warts more often confluent $\ldots . . S$. jilinensis

6. Ascospores ellipsoidal, more than $18 \times 11 \mu \mathrm{m}$ 
589

590

591

592

593

594

595

596

597

598

599

600

601

602

603

604

605

606

607

608

609

610

611

612

613

614

615

616

617

618

619

620

621

622

623

624

625

7. Ascospores av. $20.2 \times 11.7 \mu \mathrm{m}$; warts often more than $1.2 \mu \mathrm{m}$ high; apical cell of paraphyses spadiceiform and uniform in width

S. badio-berbis

7. Ascospores av. $18.3 \times 10.7 \mu \mathrm{m}$; warts mostly less than $1.2 \mu \mathrm{m}$ high; apical cell of paraphyses sinuous and not enlarged S. colensoi

8. Marginal hairs mostly $400-800 \mu \mathrm{m}$........................................... 9

8. Marginal hairs less than $400 \mu \mathrm{m}$.............................................. 10

9. Wall ornamentation tuberculate; warts rounded, isolated

S. aff. patagonica

9. Wall ornamentation verrucose; warts variable in shape, often confluent

S. aff. olivascens

10. Marginal hairs mostly less than $300 \mu \mathrm{m}$; ascospores less than $22 \mu \mathrm{m}$ long ...... $S$. ahmadiopsis

10. Marginal hairs often longer than $300 \mu \mathrm{m}$; ascospores more than $22 \mu \mathrm{m}$ long ...... $S$. nigrohirtula

\section{Excluded species and questionable records}

Scutellinia erinaceus (Schwein.) Kuntze, Rev. Gen. P1. 2: 869 (1891)

Cho \& Lee (2002) recorded this species for the first time in Korea, but the record is questionable. They did not describe the wall ornamentation of the ascospores, one of the most important features for species delimitation in Scutellinia. Besides, the diameter of apothecia, size and shape of ascospores and occurrence on wood are more similar to those characters as described for $S$. setosa than for $S$. erinaceus. Schumacher (1990) describes S. erinaceus with apothecia of 5-6 $\mathrm{mm}$ diam, 2-3 mm wider than in the Korean material. The ascospore size (19.1-24.6 x 13.0-16.8 $\mu \mathrm{m})$ of $S$. erinaceus is also clearly larger than those from Korea (17.5-20 x 10-12.5 $\mu \mathrm{m})$. In addition, this species has been found only in USA (Schumacher 1990), and the specimens reported from China of $S$. erinaceus were indeed morphologically near to S. subhirtella (see Zhuang 1994).

\section{Scutellinia kerguelensis (Berk.) Kuntze, Rev. Gen. P1. 2: 869 (1891)}

Previously Park et al. (1994) and Jung (1995) recorded this species with significantly smaller ascospores (17.5-20 x 11-12.5 $\mu \mathrm{m}$ and 18-24.5 x 11-13.5 $\mu \mathrm{m}$, respectively) than described by

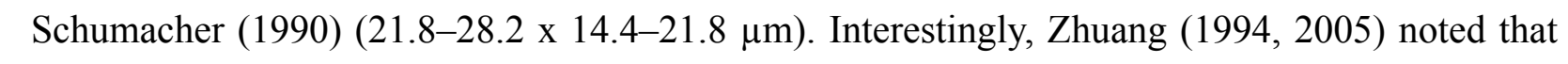
S. kerguelensis from China has smaller ascospores (19-24 x 12-15 $\mu \mathrm{m})$, for which a new variety, S. kerguelensis var. microspora, was introduced (Zhuang 2005). Morphological characteristics of the Korean specimens of S. kerguelensis (Park et al. 1994, Jung 1995) agree well with the description of the new variety. The variety was found in China (Zhuang \& Korf 1989, Zhuang 
626 1994, 2005) and similarly S. kerguelensis reported from India (Waraitch 1977) also has smaller 627 ascospres of $17.5-20.5 \times 10-13 \mu \mathrm{m}$. This suggest that this variety might be common in Asia 628 countries.

629

630 Scutellinia umbrorum (Fr.) Lambotte, Fl. Mycol. Belge, Suppl. 1: 300 (1887)

631 This species has been reported just once in Korea by Cho et al. (1997). But, the small ascospores 632 of 16-19 x 11-12 $\mu \mathrm{m}$ reported and fine wall ornamentation differ from those of $S$. umbrorum 633 (16.8-25.2 x 12.7-17.2 $\mu \mathrm{m}$ and clearly tuberculate) (see Schumacher 1979, 1990). Moreover, 634 this species was mainly found on soil and geographically is limited to Europe, but the Korean 635 specimen was collected from wet rotten wood.

636

637 Scutellinia pseudoumbrarum J. Moravec, Česká Mykol. 25: 199 (1971)

638 This species is now considered a synonym of S. umbrorum (Schumacher 1990). Cho et al. (1997) 639 recorded $S$. pseudoumbrarum for the first time in Korea, but their identification is questionable. 640 In their line drawing, the ascospores possess aculeolate-reticulate wall sculpturing, while both $S$. 641 pseudoumbrarum and S. umbrorum have remarkably tuberculated spores (Moravec 1971, 642 Kullman 1982, Schumacher 1990). The description of Cho et al. (1997) suggests that their 643 fungus is more similar to another Korean species, S. jejuensis (Han et al. 2010), in possessing 644 aculeolate-reticulate ascospore ornamentation and it occurrance on soil in the southern regions of 645 Korea.

646

\section{Acknowledgements}

648 Young-Joon Choi was supported on a fellowship provided by the National Research Foundation 649 of Korea (no. NRF-2009-352-C00119).

650

\section{References}

652 BOGACHEVA, A. \& B. B. KULLMAN (2006): Species of the genus Scutellinia (Pyronemataceae, 653 Pezizales) in Russia. [in Russian]. - Mikologiia I Fitopatologia 40 (3): 190-201.

654 CAO, J.Z. \& J. MORAVEC (1988 [1989]): Scutellinia fujianensis sp. nov., a new species from 655 China,with notes on related species. - Mycol. Helv. 3(2): 183-190.

656 CHO, D.-H. \& J.-I. LEE (2002): Notes on the Korean Ascomycetes (IX). Plant Resources - 5(2): 657 109-113.

658 CHO, D.-H., K. C. KANG \& H. J. PARK (1997): Notes on the Korean Ascomycetes (V). 659 Korean J. Plant Resources 10(4): 369-374.

660 COOKE, M. C. (1879): Mycographia, seu icones fungorum. Vol. 1. Discomycetes. - Williams and 661 Norgate, London.

662 DENISON, W. C. (1959 [1960]): Some species of the genus Scutellinia. - Mycologia 51: 605-635. 
663 DONADINI, J. C. (1983): Le genre Scutellinia (Cooke) Lamb. (I) La Section Trechispora Le Gal. - Doc. 664 Mycol. 13(49): 9-37.

665 DOUANLA-MELI, C. \& E.LANGER (2005): Notes on Discomycetes (Helotiales, Pezizales): New 666 species and new records from Cameroon. - Mycotaxon 92: 223-237.

667 GAMUNDI, I. J. (1956): El genero Scutellinia en la Argentina. - Contr. Ci. Univ. Buenos Aires Fac. Ci. 668 Exact, Ser. Bot. 1: 69-88.

669 GAMUNDI, I. J. (1975): Fungi Ascomycetes Pezizales. In: Guarrera SA, Gamundí de Amos I, de 670 Halperin DR (eds) Fl Criptog Tierra del Fuego 10 (3). - Fundación para la Educatión, la Ciencia y la 671 Cultura, Buenos Aires, pp 1-173.

672 HAN J. G., Y. J. CHOI, D. H. PFISTER \& H. D. SHIN (2010): Scutellinia jejuensis (Pezizales), a new 673 species from Korea. - Mycotaxon 112: 47-53.

674 HANSEN, L. \& H. KNUDSEN (2000): Nordic Macromycetes. Vol. 1. Ascomycetes. - Nordsvamp, 675 Copenhagen.

676 HIRSCH, G. (1985): Einige Bemerkungen zur Gattung Scutellinia. - Mykol. Mitt.-B1. 28(1): 21-29.

677 JUNG, H. S. (1995): Fungal flora of Ullung Island (VI) - on ascomycetous, auriculariaceous, and 678 gasteromycetous fungi. - Kor. J. Mycol. 23: 1-9.

679 KAUSHAL, S. C., R. KAUSHAL \& G. S. RAWLA (1983): Genus Scutellinia from India, its taxonomy, 680 nomenclature and affinities. - Bibl. Mycol. 91: 583-608.

681 KORF, R. P. \& T. SCHUMACHER (1986): Proposal to conserve Scutellinia against Patella (Fungi). 682 Taxon 35(2): 378-381.

683 KORF, R. P. \& W.-Y. ZHUANG (1991): A preliminary discomycete flora of Macaronesia: part 16, 684 Otideaceae, Scutellinioideae. - Mycotaxon 40: 79-106.

685 KULlMAN, B. (1982): A revision of the genus Scutellinia (Pezizales) in Soviet Union. - Scripta Mycol. 686 10: 1-158.

687 LAMBOTTE, E. (1887): La flore mycologique de la Belgique. Premier supplement: comprenant les 688 Hyménomycètes - Pyrénomycètes, Discomycètes (Fl. mycol. Belge, Suppl. 1). - F. Hayes, Bruxelles.

689 LE GAL, M. (1953): Les Discomycetes de Madagascar. - Prodr. Fl. Mycol. Madagascar 4: 1690465.

691 LE GAL, M. (1966): Contribution a la connaissance du genre Scutellinia (Cooke) Lamb. emend. 692 Le Gal. (1 ${ }^{\text {re }}$ étude). - Bull. Soc. Mycol. Fr. 82: 301-334.

693 LE GAL, M. (1968 [1969]): Contribution a la connaissance du genre Scutellinia (Cooke) Lamb. 694 emend. Le Gal. ( $2^{\mathrm{e}}$ étude). - Bull. Soc. Mycol. Fr. 84: 375-380.

695 LE GAL, M. (1972): Contribution a la connaissance du genre Scutellinia (Cooke) Lamb. emend. Le Gal 696 ( $3^{\text {re }}$ étude). - Bull. Soc. Mycol. Fr. 87: 433-440.

697 LE GAL, M. (1974): Valeur taxinomique de la pilosité dans le genre Scutellinia (Cooke) Lamb. emend. 698 Le Gal. - Bull. Soc. Linn. Lyon, Num. spécial 43: 227-231.

699 LEE, J. Y. \& D. H. CHO (1975): Notes on Korean higher fungi. - Kor. J. Mycol. 3(2): 13-18. 
700 LIU, M. H. \& H. W. PENG (1996): Scutellinia sinensis, a new spherical-spored species of 701 Scutellinia. - Acta Mycol. Sinica 15: 98-100.

702 LIU, C. Y. \& W.-Y. ZHUANG (2006): Relationships among some members of the genus Otidea 703 (Pezizales, Pyronemataceae). - Fung. Diversity 23: 181-192.

704 MATOČEC, N. (2000): The genus Scutellinia (Pezizales) in Croatia III. A new species 705 Scutellinia tuberculata. - Mycotaxon 76: 481-488.

706 MORAVEC, J. (1971): Some operculate Dsicomycetes from the park in Ilidza near Sarajevo (Jugoslovia). 707 - Česká Mykol. 25: 197-202.

708 MORAVEC, J. (1974): Several operculate Discomycetes from Greece and remarks on the genus 709 Scutellinia (Cooke) Lamb. Emend. Le Gal. - Česká Mykol. 28: 19-25.

710 MORAVEC, J. (1978): Fungi of Kilimanjaro - I. Discomycetes, Pezizales. - Česká Mykol. 32: 70-77.

711 OTANI, Y. 1971. Enumeration of the Sarcoscyphaceae and Scutellinia (Humariaceae). In: Kobayasi, Y 712 (ed.) Mycological reports from New Guinea and the Solomon Islands. - Bull. Nat. Sci. Mus., Tokyo 16: 713 401-422.

714 PARK, P. J., J. Y. LEE \& Y. OTANI (1994): Taxonomical studies on Ascomycotina in Korea (I). 715 - Kor. J. Mycol. 22: 100-106.

716 PERRY, B. A., K. HANSEN \& D. H. PFISTER (2007): A phylogenetic overview of the family 717 Pyronemataceae (Ascomycota, Pezizales). - Mycol. Res. 111: 549-571.

718 PERRY, B. A. \& D. H. PFISTER (2008): Chaetothiersia vernalis, a new genus and species of 719 Pyronemataceae (Ascomycota, Pezizales) from California. - Fung. Diversity 28: 65-72.

720 SCHUMACHER, T. (1979): Notes on taxonomy, ecology, and distribution of operculate discomycetes 721 (Pezizales) from river banks in Norway. - Norweg. J. Bot. 26: 53-83.

722 SCHUMACHER, T. (1988): The Scutellinia battle; the lost, missing, and dead. - Mycotaxon 33: 149723189.

724 SCHUMACHER, T. (1990): The genus Scutellinia (Pyronemataceae). Opera Bot. 101: 1-107.

725 SVRČEK, M. (1981): Katalog operkulátnich discomycetu (Pezizales) Ceskoslovenska II. (O W). 726 Česká Mykol. - 35:64-89.

727 SVRČEK, M. (1971): Tschechoslowakische Arten der Diskomyzetengattung Scutellinia (Cooke) Lamb. 728 emend. Le Gal (Pezizales) 1. - Česká Mykol. 25: 77-87.

729 TAMM, H., K. PÕLDMAA \& B. KULLMAN (2010): Phylogenetic relationships in genus Geopora 730 (Pyronemataceae, Pezizales). - Mycol. Prog. 9: 509-522.

731 WARAITCH, K. S. (1977): Some Indian Scutellinia species. Trans. Brit. Mycol. Soc. 68: 37-44.

732 YAO, Y. J. \& B. M. SPOONER (1996): Notes on British species of Scutellinia. Mycol. Res. 100: 859733865.

734 YU, Z.-H., W.-Y. ZHUANG, S. L. CHEN \& C. DECOCK (2000): Preliminary survey of 735 Discomycetes from the Changbai Mountains, China. - Mycotaxon 75: 395-408. 
ZHUANG, W.-Y. (1989): Some new species and new records of Discomycetes in China. III. - Mycotaxon

737

738

739

740

741

742

743

744

745

746

747

748

749

750

751

752

753

754

755

756

757

758

759

760

761

762

763

764

765

766

767

768

769

770

771

35: 297-312.

ZHUANG, W.-Y. (1994): Current understanding of the genus Scutellinia (Pezizales, Otideaceae) in China. - Mycosystema 6: 13-24.

ZHUANG, W.-Y. (1997): Fungal flora of the Daba Mountains: Discomycetes. - Mycotaxon 61: 3-12.

ZHUANG, W.-Y. (1998): A list of discomycetes in China. - Mycotaxon 67: 365-390.

ZHUANG, W.-Y. (2005): Re-disposition of specimens filled under Lachnea in HMAS. - Fung. Diversity 18: 211-224.

ZHUANG, W.-Y. \& R. P. KORF (1989): Some new species and new records of Discomycetes in China. III. - Mycotaxon 35: 297-312.

ZHUANG, W.-Y. \& Z. WANG (1998a): Some new species and new records of Discomycetes in China. VIII. - Mycotaxon 66: 429-438.

ZHUANG, W.-Y. \& Z. WANG (1998b): Discomycetes of tropical China. II. Collections from Yunnan. Mycotaxon 69: 339-358.

ZHUANG, W.-Y. \& Z.-I. YANG (2008): Some pezizalean fungi from alpine areas of Southeastern China. - Mycol. Montenegrina 10: 235-249.

\section{FIGURE CAPTIONS}

Fig. 1. Ascomata and ascospores (SEM) of Scutellinia species recognized in Korea. A-D: $S$. ahmadiopsis, E-H: S. badio-berbis, I-L: S. colensoi, M-P: S. aff. olivascens, Q-T: S. aff. patagonica, U-X: S. scutellata. First and second column: ascomata, third and fourth columns: ascospores (scale bar $=10 \mu \mathrm{m})$.

Fig. 2. Scutellinia orientalis (KUS-F50264 - holotype). A-B: fresh apothecia on damp wood, C: dried apothecia with long marginal hairs, D: marginal and lateral hairs, E: multi-furcated base of marginal hairs. F-H: broadly ellipsoidal to ellipsoidal ascospores sculpturing tuberculate ornamentations stained on Cotton Blue in lactic acid, note on mostly isolated but rarely interconnected tubercles, F-H: ascospores in SEM. Scale bars $=5 \mathrm{~mm}$ for A-C, $500 \mu \mathrm{m}$ for D, $20 \mu \mathrm{m}$ for $\mathrm{E}$, and $10 \mu \mathrm{m}$ for $\mathrm{F}-\mathrm{J}$. 